\title{
Resolving the Issue of the Target of Vowel Copy in Fijian Loanwords
}

\author{
Gakuji Kumagai \\ Tokyo Metropolitan University/JSPS
}

\section{Introduction}

English loanwords into Fijian undergo vowel epenthesis, as Fijian disallows coda consonants and consonant clusters. Vowel copy is an option for determining epenthetic vowel quality in loanword adaptation (Kumagai 2016a; Schütz 1978, 2004). The target of copy epenthesis seems to be either the preceding or following vowel of the epenthetic site. However, the choice of target vowel is indeterminate, as there is no vowel copy in Fijian native phonology ${ }^{1}$; this is a logical problem of loanword adaptation (see Kumagai 2016a, 2016b, 2016c for discussion).

This paper offers a resolution to the problem by adopting an expanded version of prosodic projection theory (Martínez-Paricio 2012, 2013: henceforth, MP), in which feet are allowed to exhibit maximal/minimal projection. I propose Foot Condition, which requires the Foot $[ \pm \max / \pm \min ]$ to circumscribe the vowel copy domain.

The structure of this paper is as follows. Section 2 provides the background on recursive structure in phonology, and a brief explanation of prosodic projection theory and its expanded version. Section 3 discusses copy epenthesis in Fijian loanwords; Section 4 reviews analyses without recursive structure, and Section 5 is a brief conclusion.

\section{Theoretical Background}

2.1 No recursion in phonology Let us begin with the background of recursive structure in phonology. The term recursion is defined here as a structure in which a category $\alpha$ dominates the same type of category. While recursive structure is admitted in generative syntax, in phonology recursion is considered undesirable (see Neeleman \& van de Koot 2006; Pinker \& Jackendoff 2005 for discussion). In fact, even in literature on phonology, recursion is viewed as undesirable. For example, the Strict Layer Hypothesis (henceforth, SLH: e.g., Nespor \& Vogel 1986/2007; Selkirk 1984; inter alia) maintains that a constituent of category-level $\alpha$ in the prosodic hierarchy must dominate another constituent of category-level $\alpha-1$, or must be dominated by another constituent of category-level $\alpha+1$. In other words, the SLH disallows a constituent of a particular prosodic category $\alpha$ to dominate another of the same category $\alpha$ (i.e., recursion) and also prohibits a constituent of $\alpha$ from immediately dominating a constituent of $\alpha-2$ (i.e., level-skipping) (Selkirk 2009).

However, such structures have been replaced with Optimality-Theoretic violable constraints (Selkirk 1996) (see Itô \& Mester 2013; Selkirk 2009 for discussion), as there is growing evidence that recursion and level-skipping can be admitted in particular levels of prosodic hierarchy (Intonational phrases, Phonological phrases, and Prosodic Word) (see Itô \& Mester 2013; MP 2013; and the reference cited therein $)^{2}$.

\footnotetext{
* Portions of this paper were presented at the Annual Meeting on Phonology in October 2015 (UBC) and the 10th Phonology Festa in March 2015 (Atami, Japan). I would like to thank John Alderete, Jeroen Breteler, Takeru Honma, Kie Zuraw, and four anonymous $A M P$ reviewers for their comments. This study is supported by Japan Society for the Promotion of Science (JSPS) KAKENHI Grant Number 15J04596. All errors are my responsibility.

${ }^{1}$ However, it seems that there are vowel co-occurrence restrictions in native words (Krupa 1966; Alderete \& Finley to appear).

${ }^{2}$ The advocates of the SLH originally assumed level repetition (e.g., Nespor \& Vogel 1983; Selkirk 1980).

(C) 2016 Gakuji Kumagai

Proceedings of AMP 2015

Completed March 25, 2016
} 
2.2 Prosodic Projection Theory For recursive structure, Itô \& Mester (2007 et seq.) proposed prosodic projection theory (henceforth, PPT), in which prosodic categories are allowed to show maximal/minimal projection and head/non-head. It should be noted that recursive categories are limited to Prosodic Word and the prosodic categories above it (i.e., Phonological Phrases and Intonational Phrases). In fact, Itô \& Mester (2009a) do not assume syllables and feet to be recursive. Also, Kabak \& Revithiadou (2009:105) remark that "it is still an open question whether there is recursivity below the level of the PW [Prosodic Word]." However, being an "open" question, we hope that there may be room for finding evidence of recursive feet or syllables. This paper pursues that possibility.

2.3 Expanded Prosodic Projection Theory MP $(2012,2013)$ expands on Itô \& Mester's PPT, suggesting that feet can also be recursive. In this paper, her suggestion is called the expanded prosodic projection theory (henceforth, EPPT). Projection of feet is defined in (1) and illustrated in (2).

(1) Definitions of projection of feet (Ф) (Martínez-Paricio 2012:264)

a. Maximal projection of $\Phi$ : $\Phi$ not dominated by $\Phi$

b. Minimal projection of $\Phi: \Phi$ not dominating $\Phi$

(2) Projections of Foot (Ф) (Martínez-Paricio 2013:57, with a slight modification)

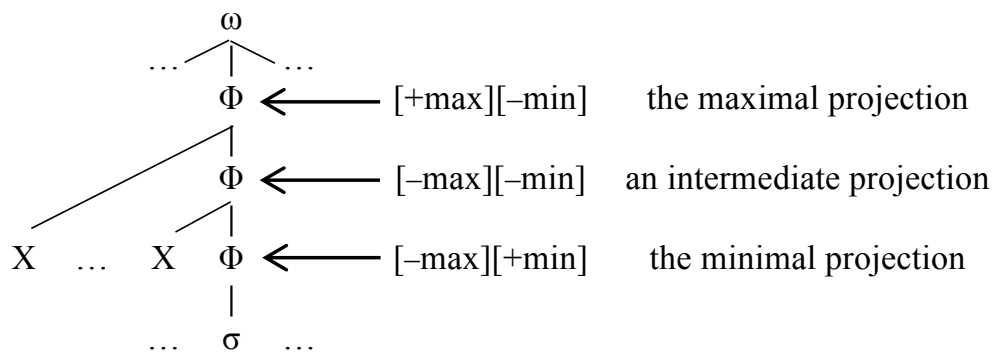

Suppose, here, a language with trochaic feet. With two binary features $[ \pm \max ]$ and $[ \pm \min ]$, four types of feet are illustrated in (3). Foot [ $+\mathrm{min}]$ is referred to as a minimal foot, and Foot[-min] as a recursive foot. Foot $[+\max ][-\min ]$ in (3a) is a foot that dominates another foot, but is not dominated by other feet. Foot[$\max ][+\min ]$ in $(3 \mathrm{a})$ is dominated by a recursive foot, but dominates no feet. MP $(2012,2013)$ argues that recursive feet are last resort devices to not leave syllables unparsed into feet, or to not build degenerate feet. Foot $[+\max ][+\min ]$ in $(3 \mathrm{~b})$ neither dominates any feet nor is dominated by any feet. Foot[-max $][-\min ]$ in (3c) is dominated by a recursive foot, and dominates another foot. In fact, this might be improbable in natural language, due to the joint effect of other prosodic constraints (e.g. LAPSE; EXHAUSTIVITY) (MP 2012). As mentioned in Section 3.3, Fijian allows the structures in (3a) and (3b) but disallows the structure in $(3 \mathrm{c})$ because of the LAPSE- 2 constraint.

(3) Projections of Foot (Ф) (Martínez-Paricio 2012:264)

a.

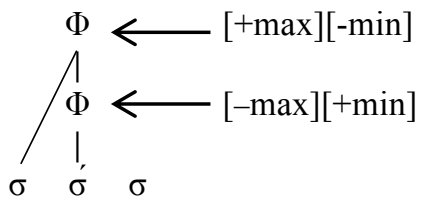

b.

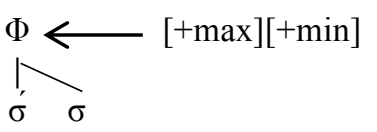

c.

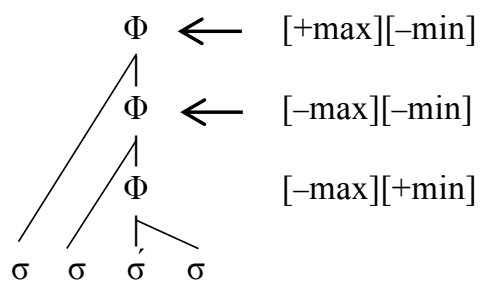

To summarize, this paper invokes the EPPT in order to address the logical problem of the target of vowel copy in Fijian loanwords, which will be discussed in detail in the next section. 


\section{Vowel Copy in Fijian Loanwords}

3.1 Vowel epenthesis in Fijian loanwords A brief explanation of Fijian consonants is necessary to provide background on the discussion. The Fijian phonemes are shown in Table 1: we refer to $/ \mathrm{p}, \mathrm{b}, \mathrm{f}, \beta, \mathrm{m} /$ as labial consonants, /t, $\mathrm{d}, \mathrm{s}, \mathrm{t}, \mathrm{n} /$ as coronal consonants, and /k, g, $\mathrm{y} /$ as dorsal consonants. ${ }^{3}$ This paper uses the phonemic transcription in the examples.

Table 1. Fijian Consonant Inventory ${ }^{4}$ (/p, f/ only used in loanwords)

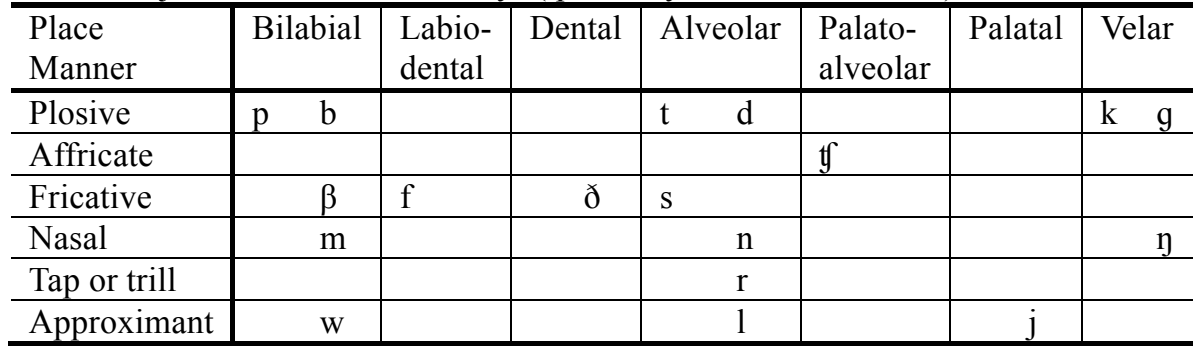

For epenthetic vowel quality in Fijian loanwords, Kumagai (2016a) provides an analysis based on a database compiled from Schütz (1978) and Gatty (2009). He shows that it is determined by repair strategies such as articulatory assimilation of the tautosyllabic consonant, vowel copy, and a default vowel epenthesis /i/ (see Section 4.1 for reviewing Schütz's (1978) analysis).

Conditions of vowel copy in Fijian loanwords are briefly described in (4). ${ }^{5}$ The data (5) and (6) illustrate copy epenthesis in word-final position and word-initial position, respectively. The (highlighted) epenthetic vowel copies the adjacent vowel.

(4) Vowel copy in Fijian

a. If an epenthetic vowel is inserted after the coda consonant (i.e., $\mathrm{C}_{1} \mathrm{~V}_{1} \mathrm{C}_{2} \rightarrow \mathrm{C}_{1} \mathrm{~V}_{1} \mathrm{C}_{2} \mathrm{v}$ ), and if the preceding consonant $\left(\mathrm{C}_{2}\right)$ is dorsal, liquid, or labial, then the epenthetic vowel ( $\underline{\mathrm{v}}$ ) tends to copy the adjacent vowel $\left(\mathrm{V}_{1}\right)$.

b. If an epenthetic vowel is inserted between a consonant cluster (i.e., $\mathrm{C}_{1} \mathrm{C}_{2} \mathrm{~V}_{2} \rightarrow \mathrm{C}_{1} \underline{\underline{v}} \mathrm{C}_{2} \mathrm{~V}_{2}$ ), and if sonority rises from $\mathrm{C}_{1}$ to $\mathrm{C}_{2}$ of the cluster, then the epenthetic vowel ( $\mathrm{v}$ ) tends to copy the adjacent vowel $\left(\mathrm{V}_{2}\right){ }^{6}$

(5) Copy epenthesis in word-final position $\left(\mathrm{C}_{1} \mathrm{~V}_{1} \mathrm{C}_{2} \rightarrow \mathrm{C}_{1} \mathrm{~V}_{1} \mathrm{C}_{2} \underline{\mathrm{v}}\right)$

a. $\mathrm{C}_{2}=$ Dorsal

\begin{tabular}{|c|c|c|c|c|c|c|c|c|}
\hline tick & $\rightarrow$ & tíki & cak & $\rightarrow$ & kéke & wélding & $\rightarrow$ & \\
\hline pink & $\rightarrow$ & pígi & $\mathrm{ck}$, jack & $\rightarrow$ & tféke & óng & $\rightarrow$ & \\
\hline & $\rightarrow$ & wini $\mathbf{i}$ & ark & $\rightarrow$ & ka & & $\rightarrow$ & \\
\hline & $\rightarrow$ & ríni & & $\rightarrow$ & $\begin{array}{l}\text { kóko } \\
\text { bulóko }\end{array}$ & $\begin{array}{l}\text { Píng-Pong } \\
\text { clock }\end{array}$ & $\rightarrow$ & \\
\hline
\end{tabular}

b. $\mathrm{C}_{2}=$ Lateral

\begin{tabular}{llllllll}
\hline bill $\rightarrow$ & bíli & roll & $\rightarrow$ & rólo & Mòntreál & $\rightarrow$ & mònotìriólo \\
ball $\rightarrow$ pólo & stall & $\rightarrow$ & sitólo & Métropole & $\rightarrow$ & mè:tòropólo \\
& & décimal & $\rightarrow$ & dèsimólo & tòwn háll & $\rightarrow$ & tàunaólo
\end{tabular}

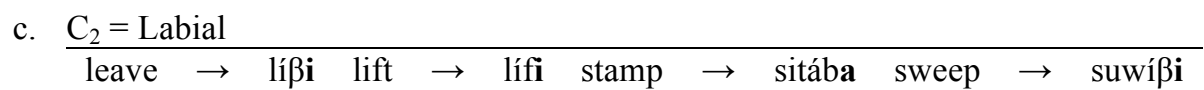

\footnotetext{
${ }^{3}$ Kumagai (2016a) claims that the Fijian liquids are underspecified for place features.

${ }^{4}$ The Fijian phonemes are represented orthographically and realized phonetically as follows: $<\mathrm{p}>/ \mathrm{p} /[\mathrm{p}] ;<\mathrm{b}>/ \mathrm{b} /[\mathrm{mb}]$; $<\mathrm{t}>/ \mathrm{t} /[\mathrm{t}] ;<\mathrm{d}>/ \mathrm{d} /[\mathrm{nd}] ;<\mathrm{k}>/ \mathrm{k} /[\mathrm{k}] ;<\mathrm{q}>/ \mathrm{g} /[\mathrm{ng}] ;<\mathrm{f}>/ \mathrm{f} /[\mathrm{f}] ;<\mathrm{v}>/ \beta /[\beta] ;<\mathrm{c}>/ \mathrm{d} /[\mathrm{d}] ;<\mathrm{s}>/ \mathrm{s} /[\mathrm{s}] ;<\mathrm{j}>/ \mathrm{g} /[\mathrm{t}] ;<\mathrm{m}>/ \mathrm{m} /$ $[\mathrm{m}] ;<\mathrm{n}>/ \mathrm{n} /[\mathrm{n}] ;<\mathrm{g}>/ \mathrm{y} /[\mathrm{n}] ;<\mathrm{l}>/ 1 /[1] ;<\mathrm{r}>/ \mathrm{r} /[\mathrm{r} \sim \mathrm{r}] ;<\mathrm{w}>/ \mathrm{w} /[\mathrm{w}],<\mathrm{y}>/ \mathrm{j} /[\mathrm{j}] ;<\mathrm{dr}>/ \mathrm{dr} /[\mathrm{nr}]$. /dr/ is excluded in the inventory table as it is difficult to classify (see Schütz 1985 for its phonetic realization).

${ }^{5}$ Note that copy epenthesis is not the sole repair strategy that invariably applies, even if conditions are met.

${ }^{6}$ Note that the epenthetic vowel on the initial syllable selects articulatory assimilation, as $\mathrm{sC}$ clusters do not show copy epenthesis (see Kumagai 2016a for specific examples).
} 
(6) Examples in word-initial position $\left(\mathrm{C}_{1} \mathrm{C}_{2} \mathrm{~V}_{2} \rightarrow \mathrm{C}_{1} \underline{\underline{\mathrm{v}}} \mathrm{C}_{2} \mathrm{~V}_{2}\right)$

\begin{tabular}{|c|c|c|c|c|c|c|c|c|}
\hline bróther & $\rightarrow$ & baráða & brick & $\rightarrow$ & biríki & brake & $\rightarrow$ & beréki \\
\hline brass & $\rightarrow$ & ßarása & plan & $\rightarrow$ & peléni & Brísbane & $\rightarrow$ & birìsibéni \\
\hline brandy & $\rightarrow$ & berédi & brush & $\rightarrow$ & barási & cross & $\rightarrow$ & kolósi \\
\hline trump & $\rightarrow$ & tarábu & train & $\rightarrow$ & teréni & crócodile & $\rightarrow$ & koròkotáile \\
\hline class & $\rightarrow$ & kalási & gram & $\rightarrow$ & garámu & Grégory & $\rightarrow$ & kerè:korí: \\
\hline clear & $\rightarrow$ & kilía & grease & $\rightarrow$ & girísi & & & \\
\hline
\end{tabular}

Determining the target of vowel copy is more complicated in word-medial position. It seems that, when an epenthetic vowel breaks up a sonority-rising cluster, it copies the vowel after the second consonant of the cluster, as shown in (7a). It also seems that when an epenthetic vowel breaks up a sonority-falling cluster, its preceding vowel is targeted, as shown in (7b). This is not true of all cases, however. To take /fèperuéri/ 'February' and /ìniládi/ 'England' for example, even when the cluster has a sonority-rising sequence (i.e., $/ \mathrm{pr} /$ and $/ \mathrm{yl} /$ ), the epenthetic vowel copies its preceding vowel rather than its following vowel. These examples suggest that the target of vowel copy may be governed by other factors.

(7) Word-medial position

a. Copying the following vowel (i.e., $\mathrm{C}_{1} \mathrm{C}_{2} \mathrm{~V}_{2} \rightarrow \mathrm{C}_{1} \underline{\underline{\mathrm{v}}} \mathrm{C}_{2} \mathrm{~V}_{2}$ )

\begin{tabular}{|c|c|c|c|c|c|c|c|c|}
\hline stri & $\rightarrow$ & sita & & $\rightarrow$ & & & $\rightarrow$ & \\
\hline cón & $\rightarrow$ & kòn & tele & $\rightarrow$ & tàlik & pro & $\rightarrow$ & \\
\hline & $\rightarrow$ & & & $\rightarrow$ & & & $\rightarrow$ & \\
\hline Mìcronésia & $\rightarrow$ & màikòronisía & nítrogen & $\rightarrow$ & nàitòrotfíni & Métropole & $\rightarrow$ & mè:tòropólo \\
\hline
\end{tabular}

b. Copying the preceding vowel $\left(\mathrm{C}_{1} \mathrm{~V}_{1} \mathrm{C}_{2} \rightarrow \mathrm{C}_{1} \mathrm{~V}_{1} \mathrm{C}_{2} \underline{\mathrm{v}}\right)$

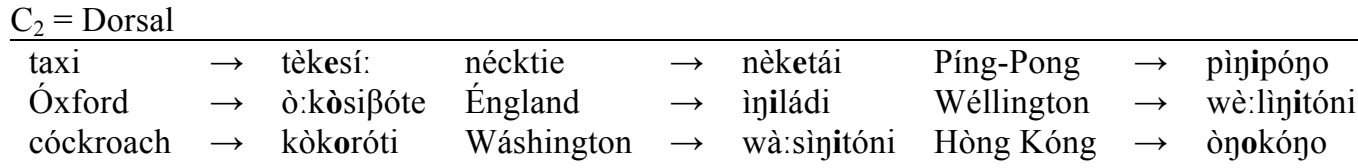

\begin{tabular}{|c|c|c|c|c|c|c|c|c|}
\hline & & & & & & S & & \\
\hline vélvet & $\rightarrow$ & $\beta$ èle $\beta$ éti & belt & $\rightarrow$ & bè:léti & Málta & $\rightarrow$ & mòlotá: \\
\hline dólphin & $\rightarrow$ & dòlofíni & Octóber & $\rightarrow$ & òkotó $\beta \mathrm{a}$ & smállpox & $\rightarrow$ & simòlopò:kísi \\
\hline
\end{tabular}

\begin{tabular}{llllll}
$\mathrm{C}_{2}=$ Labial & & & & & \\
\hline Fébruary & $\rightarrow$ & fèperuéri & table & $\rightarrow$ & tè:péli \\
Ápril & $\rightarrow$ & èperéli & cable & $\rightarrow$ & kè:ßéli
\end{tabular}

This paper stands in a position where prosodic categories play a role in accounting for phonological processes. Specifically, based on the assumption that feet exhibit recursion in Fijian, I propose that foot structure plays an important role in determining the target of vowel copy.

3.2 Non-recursive feet in Fijian This section explains minimal feet in Fijian. Fijian is a stress language; in Fijian, bimoraic trochee feet are formed from the right edge of the word, though degenerate feet are not formed (Hayes 1995). Primary stress is placed on the penultimate mora (Blevins 1994). Illustrative examples are presented in (8).

(8) Native Fijian words (Feet $[+\mathrm{min}]$ are denoted by parentheses)

\begin{tabular}{llllll}
\hline (líma) & 'five' & (bú:) & 'grandmother' & ma(káwa) & 'old' \\
tu(rána) & 'men' & se(yái) & 'no' & (màđa)(wá:) & 'worthless' \\
ma(ráma) & 'women' & (bè:)(bé:) & 'moth' & (mà:)(ðáwa) & 'week'
\end{tabular}


As presented in (9), loanwords obey the prosodic system in the same way as Fijian native words. ${ }^{7}$ Consequently, loanwords invariably follow ALIGN-Right (the rightmost Foot[+min], PrWd) (henceforth, Align-Wd[+min]-R), and two consecutive moras must not be left unfooted (Kenstowicz 2007). This is ruled out by LAPSE-2[+min]: a kind of LAPSE constraints that penalizes a sequence of two unstressed moras (or syllables) of the word not separated by a Foot $[+\min ]$ boundary.

(9) Fijian Loanwords

\begin{tabular}{|c|c|c|c|c|c|c|c|c|}
\hline ring & $\rightarrow$ & (ríni) & béacon & $\rightarrow$ & (bì:)(kéni) & chémistry & $\rightarrow$ & (kè:)(mìsi)ti(rí:) \\
\hline belt & $\rightarrow$ & (bè:)(léti) & doctor & $\rightarrow$ & (dòke)(tá:) & proféssor & $\rightarrow$ & po(rò:)(fésa) \\
\hline bazáar & $\rightarrow$ & ba(sá:) & spínach & $\rightarrow$ & si(pì:)(nátfi) & président & $\rightarrow$ & pe(rèsi)(tédi) \\
\hline ballóon & $\rightarrow$ & ba(lúni) & pláster & $\rightarrow$ & pa(làsi)(tá:) & éstimate & $\rightarrow$ & (èsi)ti(méti) \\
\hline
\end{tabular}

There are additional requirements for constructing foot structure in loanwords. First, English loanwords in Fijian must fulfill the requirement that they preserve the original stress from the English source words (Kenstowicz 2007; Schütz 1978, 1983, 2004). This is always enforced unless loanwords undergo nativization (Kumagai 2014). Second, epenthetic vowels are prohibited from undergoing lengthening. Since long vowels are invariably stressed in Fijian, this condition can be rephrased as disallowing epenthetic vowels from receiving stress and undergoing lengthening. This condition is, in most cases, enforced in Fijian loanword adaptation. Third, epenthetic vowels are required to not be assigned stress. In other words, epenthetic vowels must not be a head of the foot. Fourth, inherited short vowels are disallowed from receiving stress and undergoing lengthening. ${ }^{8}$

(10) Conditions for constructing foot structure in loanwords

a. Preserve the original stress from the English source words. (MAX-STRESS)

b. Epenthetic vowels must not be lengthened. (Condition A)

c. Epenthetic vowels must not be stressed. (Condition B)

d. Inherited short vowels must be neither stressed nor lengthened. (Condition C)

While Condition A is inviolable, Conditions B and C are violable. Kenstowicz (2007) accounts for this by proposing Prosodic Prominence (PP) Hierarchy and related constraints in which violations are given by counting the total number of steps along the hierarchy. Further, Kumagai (2015) provides an analysis using local conjunction. With local conjunction (Smolensky 1993 et seq.), Conditions B and C can be expressed as $\{$ Dep-Vowel \& Dep-Stress (abbr. $\{$ DeP-V\&S $\}$ ), and \{DeP-Stress \& DeP-Mora $\}$ (abbr. \{Dep$S \& M\})$, respectively. In definition, $\{D E P-V \& S\}$ is violated if a vowel with no correspondent in the input is given stress in the output, and $\{$ DEP-S\&M $\}$ is violated if a vowel is stressed and lengthened in the output. ${ }^{9}$ Below, we look at specific examples showing that Conditions $\mathrm{B}$ and $\mathrm{C}$ are violable.

As shown in (11a), English words with biconsonantal cluster in coda position (i.e. CVCC) are adapted as $(\dot{\sigma}:)(\sigma \sigma){ }^{10}$ In $(11 \mathrm{~b})$, English words with triconsonantal cluster in onset position (i.e. CCCVC) are adapted as $(\dot{\sigma} \sigma)(\dot{\sigma} \sigma)$. While these two forms preserve the primary stress of the original word, they have an epenthetic vowel that lies in the head of the foot. Therefore, they violate Condition B.

(11) Violation of Condition B ( $\{$ DEP-V\&S $\})$

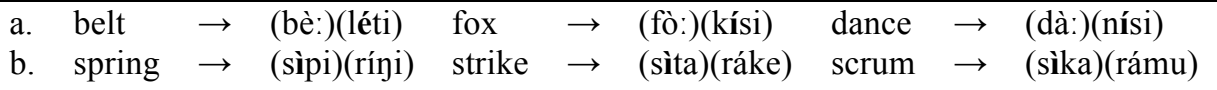

Examples in (12) show that the inherited short vowel in the final syllable is stressed and lengthened in the adapted form, which means it violates Condition C.

\footnotetext{
${ }^{7}$ There is neither form with a long vowel on the penultimate syllable (i.e., * $\left.\mathrm{CV}: \mathrm{CV} \#\right)$ nor with three consecutive short unstressed syllables (i.e., *CVCVCV) (Schütz 1978, 1983, 2004).

${ }^{8}$ To make discussion simpler, other relevant OT constraints are excluded from analysis (see Kumagai 2015 for details).

9 DEP-V\&S $\}$ and $\{$ DEP-S\&M $\}$ correspond with the PP-2 and PP-1 constraints in Kenstowicz (2007), respectively.

${ }^{10}$ Note that word-final consonant clusters are sometimes subject to deletion. See Schütz $(1978,2004)$ and Shinohara (2006) for final cluster reduction in Fijian loanword adaptation.
} 
(12) Violation of Condition C ( $\{$ DEP-S\&M $\})$

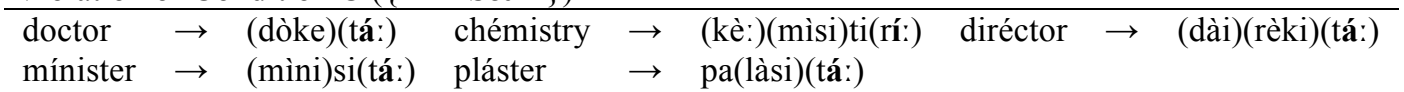

In the Optimality Theory framework (OT: Prince \& Smolensky 1993/2004), violability of Conditions $\mathrm{B}$ and $\mathrm{C}$ is guaranteed. Tableau (13) shows that Condition $\mathrm{B}(\{\mathrm{DEP}-\mathrm{V} \& \mathrm{~S}\}$ ) is ranked above AlignWd[+min]-R. For the optimal candidate (bè:)(léti), the penultimate syllable receives stress despite containing an epenthetic vowel, which leads to a violation of $\{$ DEP-V\&S $\}$.

(13) Align-Wd-R $[+\min ] »\{\mathrm{DEP}-\mathrm{V} \& \mathrm{~S}\}$

\begin{tabular}{|c|c|c|}
\hline$/ \mathrm{be}_{1} 1 \mathrm{t} /$ & Align- $\mathrm{Wd}[+\min ]-\mathrm{R}$ & DEP-V\&S \\
\hline$\rightarrow \quad\left(\right.$ bè̀ $\left._{1}\right)\left(\mathrm{lé}_{2} \mathrm{t} \mathrm{i}_{3}\right)$ & & ${ }_{1}\left(\mathrm{e}_{2}\right)$ \\
\hline$\left(b_{1} e_{2}\right) t_{3}$ & $\mathrm{~W}_{1}$ & $\mathrm{~L}$ \\
\hline
\end{tabular}

Tableau (14) shows that Condition B $(\{\mathrm{DEP}-\mathrm{V} \& S\})$ is outranked by LAPSE-2[+min]. The optimal candidate (sita) (ráke) incurs violations of $\{\mathrm{DEP}-\mathrm{V} \& \mathrm{~S}\}$, as the epenthetic vowel in the first syllable is assigned stress. Note that the losing candidate sita(ráke) has two consecutive unfooted moras, which means a violation of LAPSE- $2[+\mathrm{min}]$.

(14) LAPSE- $2[+\min ] \gg\{$ DEP-V $\& S\}$

\begin{tabular}{|l|c|c|}
\hline \multicolumn{1}{|c|}{$/ \mathrm{stri}_{3} \mathrm{ke} /$} & LAPSE- $2[+\mathrm{min}]$ & DEP-V\&S \\
\hline $\mathrm{si}_{1} \mathrm{ta}_{2}\left(\mathrm{rá}_{3} \mathrm{ke}_{4}\right)$ & $\mathrm{W}_{1}$ & $\mathrm{~L}$ \\
\hline$\rightarrow\left(\mathrm{sì}_{1} \mathrm{ta}_{2}\right)\left(\mathrm{rá}_{3} \mathrm{ke}_{4}\right)$ & & ${ }_{1}\left(\mathrm{i}_{1}\right)$ \\
\hline
\end{tabular}

Tableau (15) shows that Condition $\mathrm{C}$ is ranked below Condition B. For the optimal candidate (kè:)(misi)ti(rí), the lengthened vowel in the final syllable violates $\{\mathrm{DEP}-\mathrm{S} \& \mathrm{M}\}$, while there is no violation of $\{\mathrm{DEP}-\mathrm{V} \& \mathrm{~S}\}$ since it has no stressed epenthetic vowels. For the losing candidate (kèmi)si(tíri), the epenthetic vowel on the penultimate syllable receives stress, which invites a violation of $\{\mathrm{DEP}-\mathrm{V} \& \mathrm{~S}\}$, while there is no violation of $\{$ DEP-S\&M $\}$. Therefore, it follows that $\{\mathrm{DEP}-\mathrm{V} \& \mathrm{~S}\}$ should outrank $\{\mathrm{DEP}-$ $\mathrm{S} \& \mathrm{M}\}$. This means that DEP-V violations are more crucial than DEP-S or DEP-M violations.

(15) $\{$ DEP-V\&S $\} »\{$ DEP-S\&M $\}$

\begin{tabular}{|c|c|c|}
\hline /ché ${ }_{1} \mathrm{mi}_{2} \operatorname{stry}_{5} /$ & DEP-V\&S & DEP-S\&M \\
\hline$\left(\mathrm{kè}_{1} \mathrm{mi}_{2}\right) \mathrm{si}_{3}\left(\mathrm{t}_{1}^{\prime} \mathrm{ri}_{5}\right)$ & $\mathrm{W}_{1}\left(\mathrm{i}_{4}\right)$ & $\mathrm{L}$ \\
\hline$\left(\mathrm{kè}_{1}\right)\left(\mathrm{mì}_{2} \mathrm{si}_{3}\right) \mathrm{ti} \mathrm{i}_{4}\left(\mathrm{rí}_{5}\right)$ & & $1\left(i_{5}\right)$ \\
\hline
\end{tabular}

We saw above how minimal feet are constructed in Fijian loanwords. The next section will explain how recursive feet are formed in the EPPT framework.

3.3 Recursive feet in Fijian I propose in this paper that feet can be recursive in Fijian. As mentioned in Section 2.3, I suggest that Fijian allows prosodic structures as in (3a) and (3b), but disallows the structure shown in (3c). For the structure (3a), a stray syllable is incorporated into the following moraic trochaic foot, thereby forming a recursive foot (represented by Foot $[+\max ][-\min ])$. For (3c), there are two consecutive syllables not dominated by Foot $[+\mathrm{min}]$ and that are directly dominated by Foot[-min]. This structure, we assume, is impermissible in Fijian since it breaches the LAPSE-2[+min] constraint.

There are three points to be noted regarding recursive feet. First, Foot[-min] is binary and right-headed, in that Foot[-min] consists of a syllable on the left side and the projected foot on the right side. Second, in Fijian, a stray syllable is deemed to be incorporated into the following Foot [+min], whereas degenerate feet are still prohibited. In other words, Fijian always obeys EXHAUSTIVITY (Foot[-min]), dictating that syllables be parsed into Feet[-min], at the cost of violating the constraint prohibiting recursion (i.e., *RECURSION). Third, recursive feet are built only if they save unparsed syllables into minimal feet. No recursive structure thus arises if there is no stray syllable, as *RECURSION violations would accumulate. 
One might question whether there is independent evidence for recursive foot structure in Fijian native phonology. ${ }^{11}$ Unfortunately, it has not been attested; rather, the loanword data provides evidence for recursive foot structure in Fijian. ${ }^{12}$ However, I do not intend to claim that recursive feet are constructed only in loanwords. I hope for future research that evidence for recursive feet in Fijian will also be found in native words.

To summarize thus far: by adopting EPPT, this paper assumes that feet can be recursive in Fijian. The goal of this paper is to provide an account for the target of vowel copy in Fijian loanwords.

3.4 Vowel copy conditions I propose three conditions on the target of vowel copy in Fijian loanwords:

(16) Vowel Copy Conditions (VCC)

a. Adjacency Condition: Interacting segments are required to be as close as possible.

b. Base Condition: Copy an inherited vowel.

c. Foot Condition: Copy a vowel within the Foot $[ \pm \max / \pm \min ]$ to which the epenthetic vowel belongs.

Explanation of each condition is given below. For Adjacency Condition, given that an epenthetic vowel ( $\underline{\mathrm{v}})$ is inserted in a hypothetical form $\mathrm{CV}_{2} \mathrm{CV}_{1} \mathrm{CvCV}_{1} \mathrm{CV}_{2}$, copying $\mathrm{V}_{1}$ is favored over copying $\mathrm{V}_{2}$ because the epenthetic vowel is closer to $\mathrm{V}_{1}$ than $\mathrm{V}_{2} \cdot{ }^{13}$ Base Condition dictates that an epenthetic vowel is prohibited from copying another. Foot Condition requires copy epenthesis to occur within the Foot $[ \pm \max / \pm \mathrm{min}]$ where the epenthetic vowel belongs. This means that foot structure plays a role in delimiting the domain of vowel copy. This proposal has recourse to the assumption made in Nespor \& Vogel (1986/2007), that prosodic categories involve the domain of phonological processes.

Importantly, while Adjacency and Base Conditions are inviolable, Foot Condition is violated only if the foot containing an epenthetic vowel also contains another (see Section 3.4.3). ${ }^{14}$ For example, as seen in Section 3.2, the English word strike is adapted as (sita)(ráke). In this case, the epenthetic vowel after /t/ copies its following vowel, crossing the foot boundary. For the rest of this section, we will look at three types of vowel copy observed in Fijian loanwords.

Table 2. Three types of vowel copy in Fijian loanwords

\begin{tabular}{lcccc}
\hline & Adjacency Condition & Base Condition & Foot Condition & Domain of vowel copy \\
\hline Type I & Enforced & Enforced & Enforced & Foot[+min] \\
\hline Type II & Enforced & Enforced & Enforced & Foot[-min] \\
\hline Type III & Enforced & Enforced & Violated & - \\
\hline
\end{tabular}

3.4.1 Type I Illustrative examples are provided in (17). When an epenthetic vowel is inserted in wordfinal position, it is incorporated into a Foot $[+\mathrm{min}]$ with the preceding vowel. The epenthetic vowel copies the preceding non-epenthetic vowel within the Foot $[+\mathrm{min}]$ to which it belongs. We can therefore ensure that the examples (17) conform to all of the VCCs.

\footnotetext{
${ }^{11}$ I would like to thank an anonymous AMP reviewer for pointing out this issue.

${ }^{12}$ Kumagai (2016b) argues that EPPT is "hidden phonology"- it is available even if it does not put in an appearance in the native phonology of the language.

${ }^{13}$ It is assumed that the spreading of the feature under a V-Place should be local at the V-Place tier (e.g., Archangeli \& Pulleyblank 1994). Adjacency Condition can be referred to as Locality or Adjacency Condition (Kitto \& de Lacy 1999; Kawahara 2004).

${ }^{14}$ An anonymous reviewer pointed out why only Foot Condition can be violated. This question remains unresolved.
} 
(17) Word-final position (Relevant epenthetic vowels highlighted)

\begin{tabular}{|c|c|c|c|c|c|c|c|c|}
\hline tick & $\rightarrow$ & (tíki) & lift & $\rightarrow$ & (lífi) & wélding & $\rightarrow$ & (wèle)(díni) \\
\hline pink & $\rightarrow$ & (pígi) & bill & $\rightarrow$ & (bíli) & Hòng Kóng & $\rightarrow$ & (òyo)(kóyo) \\
\hline wing & $\rightarrow$ & (wini) & ball & $\rightarrow$ & (pólo) & gámbling & $\rightarrow$ & (gàbi)(líni) \\
\hline ring & $\rightarrow$ & (ríni) & roll & $\rightarrow$ & (rólo) & Píng-Pong & $\rightarrow$ & (pìni)(poyo) \\
\hline cake & $\rightarrow$ & (kéke) & block & $\rightarrow$ & $<$ bu(lóko) $>$ & décimal & $\rightarrow$ & (dèsi)(mólo) \\
\hline check, jack & $\rightarrow$ & (tgéke) & clock & $\rightarrow$ & $<\mathrm{ka}(\mathrm{ló} \mathrm{ko} \mathbf{0})>$ & Mòntreál & $\rightarrow$ & (mòno)(tìri)(ólo) \\
\hline mark & $\rightarrow$ & (máka) & stall & $\rightarrow$ & $<$ si(tólo)> & Métropole & $\rightarrow$ & (mè:)(tòro)(pólo) \\
\hline cork & $\rightarrow$ & (kóko) & sweep & $\rightarrow$ & $<\operatorname{su}($ wíßi) $>$ & tòwn háll & $\rightarrow$ & (tàu)na(ólo) \\
\hline leave & $\rightarrow$ & $\left(\operatorname{li}^{\prime} \mathbf{i}\right)$ & stamp & $\rightarrow$ & <si(tába)> & & & \\
\hline
\end{tabular}

As shown in (18), Type I can also be observed in word-medial position. In (18a), the epenthetic vowel is incorporated into a Foot [+min] with the preceding vowel. In (18b), the epenthetic vowel is incorporated into a Foot $[+\mathrm{min}]$ with the following vowel. Like the above data (17), the data in (18) show that the epenthetic vowel copies the inherited vowel within the Foot $[+\min ]$ where it belongs.

(18) Word-medial position (i) (Relevant epenthetic vowels highlighted)

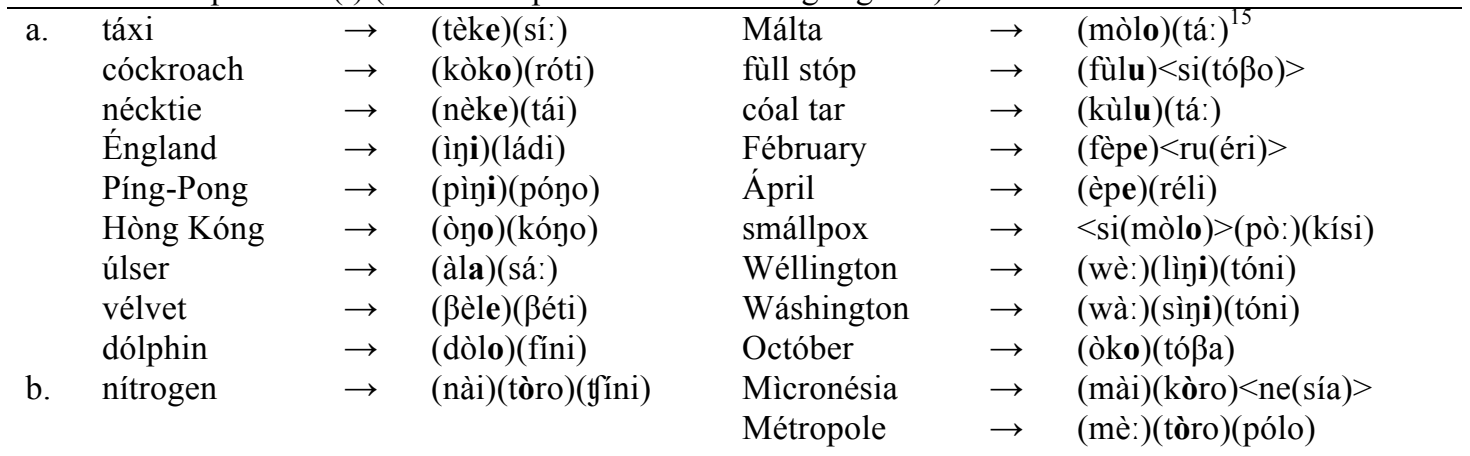

3.4.2 Type II For Type II, vowel copy occurs within recursive feet (i.e., Foot[-min]). We assume, following the EPPT, that the epenthetic vowel in (19) is parsed into a recursive foot. In Fijian, the stray syllable in the word-initial position is incorporated into a recursive foot that is right-headed (i.e. $\sigma(\sigma \sigma) \rightarrow$ $\langle\sigma(\sigma \sigma)>)$. The recursive foot contains an unstressed syllable on the left side and the projected foot on the right side. The epenthetic vowel in (19) copies the following non-epenthetic vowel, which indicates that copying vowels takes place within the recursive foot. We can therefore make sure that the data (19) follow all of the VCCs.

(19) Word-initial position (Relevant epenthetic vowels highlighted)

\begin{tabular}{|c|c|c|c|c|c|}
\hline English & & Fijian & English & & Fijian \\
\hline bróther & $\rightarrow$ & $<$ ba(ráða) $>$ & train & $\rightarrow$ & $<$ te(réni) $>$ \\
\hline brass & $\rightarrow$ & $<\beta \mathbf{a}$ (rása) $>$ & class & $\rightarrow$ & $<$ ka(lási) $>$ \\
\hline brick & $\rightarrow$ & <bi(ríki)> & clear & $\rightarrow$ & <ki(lía)> \\
\hline plan & $\rightarrow$ & $<$ pe(léni) > & gram & $\rightarrow$ & $<\mathrm{ga}($ rámu $)>$ \\
\hline brake & $\rightarrow$ & $<$ be(réki) $>$ & grease & $\rightarrow$ & $<$ gi(rísi)> \\
\hline Brísbane & $\rightarrow$ & $<$ bi (rìsi) $>$ (béni) & cross & $\rightarrow$ & $<\mathrm{ko}$ (lósi) $>$ \\
\hline brandy & $\rightarrow$ & $<$ be(rédi) $>$ & crócodile & $\rightarrow$ & <ko(ròko)>(táile) \\
\hline brush & $\rightarrow$ & $<$ ba(rási) $>$ & Grégory & $\rightarrow$ & $<\operatorname{ke}($ rè: $)><\operatorname{ko}($ rí: $)>$ \\
\hline trump & $\rightarrow$ & $<$ ta $($ rábu $)>$ & & & \\
\hline
\end{tabular}

The data (20) show that an epenthetic vowel in word-medial position copies the following vowel. In (20a), what is targeted is the following vowel rather than the preceding vowel. This can be accounted for using only Adjacency and Base Conditions, as the preceding vowel is an epenthetic vowel (i.e., a violation of Base Condition). However, an account for the examples (20b) requires Foot Condition because neither

\footnotetext{
${ }^{15}$ We can also attest mo(lóta), which is assumed to be a nativized form (see Kumagai 2014 for loanword nativization).
} 
of Adjacency Condition nor Base Condition is violated, whether the preceding vowel or the following vowel is copied. Foot Condition allows the target of vowel copy to become the following vowel within the Foot $[-\min ]$ to which the epenthetic vowel belongs.

(20) Word-medial position (Relevant epenthetic vowels highlighted)

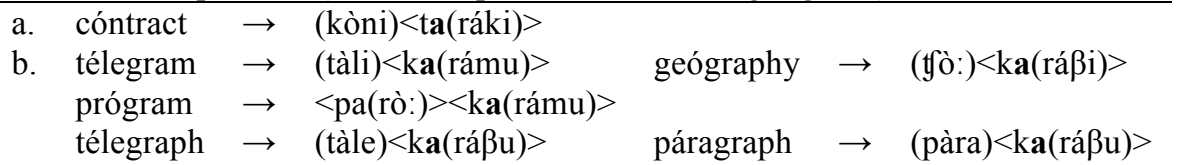

3.4.3 Type III For Type III, Foot Condition is violated while Adjacency and Base Conditions are enforced. Type III can be observed in English words with triconsonantal onset clusters or biconsonantal coda clusters.

The data (21) show that the epenthetic vowel does not copy an adjacent vowel within the Foot[+min] where it belongs but another adjacent vowel due to Base Condition. The epenthetic vowel in (21a) is incorporated into a Foot $[+\min ]$ with the preceding vowel. However, it does not copy the preceding vowel but rather the following vowel, since the preceding vowel is also an epenthetic vowel. The epenthetic vowel in $(21 \mathrm{~b})$ is incorporated into a Foot $[+\mathrm{min}]$ with the following vowel, as Align-Wd[ $+\mathrm{min}]-\mathrm{R}$ requires it to become the head of the rightmost Foot $[+\mathrm{min}]$. The target of vowel copy is the preceding vowel rather than the following vowel, since the following vowel is an epenthetic vowel.

(21) Word-medial position (ii) (Relevant epenthetic vowels highlighted)

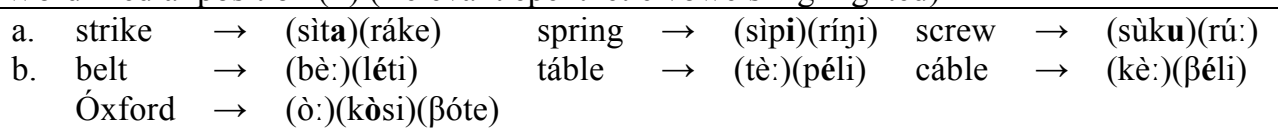

The data (21) show that the epenthetic vowel does not copy another epenthetic vowel, but instead copies its adjacent inherited vowel, meaning it conforms to Adjacency and Base Conditions, at the expense of violating Foot Condition. In other words, while Adjacency and Base Conditions are inviolable, Foot Condition is sometimes violable.

3.5 Summary To summarize, we saw three types of vowel copy in Fijian loanwords. For Type I, the epenthetic vowel copies the vowel within the minimal foot (Foot $[+\mathrm{min}])$ where it belongs. For Type II, vowel copy occurs within the recursive foot (Foot[-min]). For Type III, the epenthetic vowel does not copy the vowel within the minimal foot (Foot $[+\min ])$ where it belongs, in order to not copy any epenthetic vowels. This is the case where, while Adjacency and Base Conditions are enforced, Foot Condition is violated. In the next section, we will review three conceivable analyses without recourse to recursion.

\section{No-recursion-based Analyses Compared}

4.1 Schütz (1978) Schütz (1978:28) mentions clearly that “... in the Fijian form, the vowel corresponding to an accented vowel in the model conditions the choice of the vowel in an adjacent syllable." ${ }^{16}$ This predicts that stress position of original words can contribute to determining the target of vowel copy in Fijian. However, there are examples for which the rule does not account. The target of vowel copy in the loanwords listed in (22) is not determined by the vowel corresponding to the (underlined) stressed vowel in the English words. For example, the epenthetic vowel between $/ \mathrm{kr} /$ of the English word Micronesia does not copy the preceding vowel that is stressed in English but the following vowel /o/ (i.e., máikòronisia; *màikìronisia $)$.

(22) Unpredictable data (Stressed vowels underlined)

Mìcronésia $\rightarrow$ màikòronisía ${ }^{17}$ Métropòle $\rightarrow$ mè̀:tòropólo nítrogen $\rightarrow$ nàitòrotgíni

${ }^{16}$ This description is not found in the revised version of the paper (Schütz 2004).
${ }^{17}$ We assume that màikoronisia is a nativized form. 
4.2 Colon and Weak Layering A second alternative without recursion is to adopt different theories regarding prosodic categories. Some researchers used to propose an intermediate prosodic category such as "colon" between (minimal) feet and Prosodic Word (e.g., Halle \& Clements 1983; Hayes 1995; Tsujimura 2006). The "colon" might be better introduced if it is assumed to bear a different property from feet in the analysis of a given language. However, the EPPT-based analysis exploits projected feet in lieu of a new prosodic category, since it requires that Foot Condition in Fijian vowel copy refer not only to minimal feet but also to recursive feet. It is therefore unnecessary to assume such an otiose prosodic category, at least in the analysis of vowel copy in Fijian loanwords.

Contrary to the SLH, the Weak Layer Hypothesis (henceforth, WLH) is a well-known hypothesis admitting the skipping of a prosodic category (e.g., Itô \& Mester 1992/2003; Booij 1996). For example, a Prosodic Word is allowed to dominate different prosodic categories such as foot and syllable. Thus, if applied to Fijian cases, the stray syllable (i.e., pe in peleni; $k a$ in talikaramu) is directly incorporated into PrWd: [pe(léni) $]_{\mathrm{PrWd}} ;\left[(\text { tàli)ka(rámu) }]_{\mathrm{PrWd}}\right.$. Can the WLH predict the target of vowel copy in Fijian loanwords? The [pe(léni) $]_{\text {PrWd }}$ case runs into no problems: the fact that the epenthetic vowel in the initial syllable copies the following vowel can be explained by the Adjacency and Base Conditions. However, the case of $\left[(\text { tàli) } \mathrm{ka}(\text { rámu })]_{\mathrm{PrWd}}\right.$ is problematic: neither condition accounts for it, since it is difficult for the epenthetic vowel to differentiate the preceding vowel from the following one. If the domain of the vowel copy in Fijian loanwords were expanded to Prosodic Word, it would be too large to identify the target of vowel copy. In order to answer why the epenthetic vowel copies the following rather than the preceding vowel, it is necessary to circumscribe the domain of the vowel copy in the [(tàli)ka(rámu) $]_{\mathrm{PrWd}}$ case. In contrast to the WLH-based analysis, the EPPT-based analysis assumes that the epenthetic vowel in the stray syllable is incorporated into a recursive foot, which allows us to apply Foot Condition to the case in question.

4.3 Boundaries in Loanwords A third hypothesis for determining the target of vowel copy is to look closely at syllable or morpheme boundaries in loanwords. In other words, our concern is whether vowel copy is halted by syllable or morpheme boundaries in loanwords. ${ }^{18}$

(23) Examples (Hyphens denote syllable or morpheme boundary.)

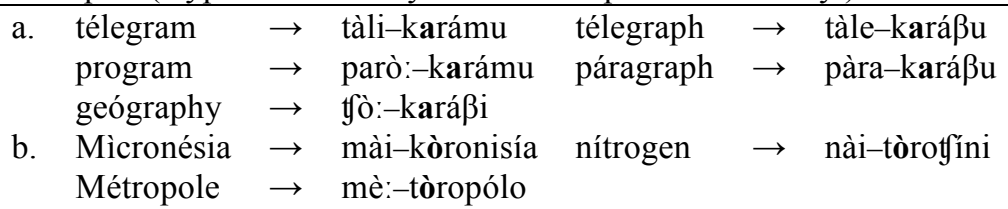

Suppose here that loanword adapters of each language must know the phonology or morphology of English that informs them of the syllable or morpheme boundary. If they assume that there is a morpheme boundary before -gram and -graph(y) in the original English words (23a), they can predict that vowel copy does not occur across the boundary. In fact, in Fijian, the English words gram and grammar are adapted as ga(rámu) and $g a($ ráma $)$, respectively. It may thus be possible to assume that Fijian adapters apply the loanwords (23a). However, the morpheme boundary is not always clear - for example, it seems that the loanwords (23b) have no clear boundary before the syllable with the highlighted epenthetic vowel. Therefore, the analysis with recourse to syllable or morpheme boundary is infeasible in the analysis of Fijian.

\section{Conclusion}

This paper addressed the logical problem of determining the target of vowel copy in Fijian loanword adaptation. The key proposal made here is Foot Condition, which requires the domain of vowel copy to be delimited by Foot $[ \pm \max / \pm \min ]$. This analysis is based on EPPT (MP 2012, 2013), in which feet are allowed to exhibit maximal/minimal projection. Future research is needed to find out evidence that recursive feet play a role in Fijian native phonology.

\footnotetext{
${ }^{18}$ Similar cases to these examples are also discussed in Shona loanword adaptation (Uffmann 2007).
} 


\section{References}

Alderete, John \& Sara Finley (to appear). Gradient vowel harmony in Oceanic. Language and Linguistics 17. Archangeli, Diana \& Douglas Pulleyblank (1994). Grounded phonology. Cambridge, MA: The MIT Press.

Blevins, Juliette (1994). The bimoraic foot in Rotuman phonology and morphology. Oceanic Linguistics 33, 491-516.

Booij, Geert (1996). Cliticization as prosodic integration: The case of Dutch. The Linguistic Review 13, $219-242$.

Gatty, Ronald (2009). Fijian-English dictionary: With notes on Fijian culture and natural history. Southeast Asia Program Publications, Cornell University Press.

Geraghty, Paul A. (1983). The history of the Fijian languages. Honolulu: University of Hawaii Press.

Haider, Hubert (1993). Deutsche Syntax - generativ. Vorstudien zur Theorie einer projektiven Grammatik. Tübingen: Gunter Narr.

Halle, Moris \& George N. Clements (1983). Problem book in phonology. Cambridge, MA. The MIT Press.

Hayes, Bruce (1995). Metrical stress theory: Principles and case studies. Chicago: The University of Chicago Press.

Itô, Junko \& Armin Mester (1992). Weak layering and word binarity. Linguistics Research Center Report No. 92-09, University of California, Santa Cruz. [A new century of phonology and phonological theory. A festschrift for Professor Shosuke Haraguchi on the occasion of his sixtieth birthday, 2003, ed. by Takeru Honma, Masao Okazaki, Toshiyuki Tabata, and Shin-ichi Tanaka, 26-65. Tokyo: Kaitakusya.]

Itô, Junko \& Armin Mester (2007). Prosodic adjunction in Japanese compounds. MIT Working Papers in Linguistics 55, 97-111. MIT Department of Linguistics and Philosophy, Cambridge, Massachusetts.

Itô, Junko \& Armin Mester (2009a). The extended prosodic word. Phonological domains: Universals and deviation, ed. by Janet Grijzenhout and Bariş Kabak, 135-194. Berlin: Mouton de Gruyter.

Itô, Junko \& Armin Mester (2009b). The onset of the prosodic word. Phonological argumentation: Essays on evidence and motivation, ed. by Steve Parker, 227-260. London: Equinox.

Itô, Junko \& Armin Mester (2010). Recursive prosodic phrasing in Japanese. Proceedings of the Japanese/Korean Conference 18, ed. by William McClure and Marcel Den Dikken, 147-164. Stanford, CA, CSLI Publications.

Itô, Junko \& Armin Mester (2012). Recursive prosodic phrasing in Japanese. Prosody matters. Essays in Honor of Elisabeth Selkirk, ed. by Toni Borowsky, Shigeto Kawahara, Mariko Sugahara, and Takahito Shinya, 280-303. London: Equinox.

Itô, Junko \& Armin Mester (2013). Prosodic subcategories in Japanese. Lingua 124, 20-40.

Kabak, Bariş \& Anthi Revithiadou (2009). An interface approach to prosodic word recursion. Phonological domains: Universals and deviation, ed. by Janet Grijzenhout and Bariş Kabak, 105-134. Berlin: Mouton de Gruyter.

Kawahara, Shigeto (2004). Locality in echo epenthesis: Comparison with reduplication. Proceedings of the NorthEastern Linguistics Society 34, ed. by Keir Moulton and Matthew Wolf, 295-309.

Kenstowicz, Michael (2007). Salience and similarity in loanword adaptation: A case study from Fijian. Language Sciences 29, 316-340.

Kitto, Catherine \& Paul de Lacy (1999). Correspondence and epenthetic quality. Proceedings of Austronesian Formal Linguistics Association VI (Toronto Working Papers in Linguistics 16(2)), ed. by Catherine Kitto and Carolyn Smallwood, 181-200.

Krupa, Viktor (1966). The phonemic structure of bi-vocalic morphemic forms in Oceanic languages. The Journal of the Polynesian Society 75, 458-497.

Kumagai, Gakuji (2014). Suprasegmental nativization of English loanwords into Fijian. Phonological Studies (Journal of the Phonological Society of Japan) 17, 19-26. Tokyo: Kaitakusya.

Kumagai, Gakuji (2015). Prosodic prominence conditions and local conjunction. Phonological Studies (Journal of the Phonological Society of Japan) 18, 27-34. Tokyo: Kaitakusya.

Kumagai, Gakuji (2016a). Vowel epenthesis of English loanwords into Fijian. Phonological Studies (Journal of the Phonological Society of Japan) 19, 27-34. Tokyo: Kaitakusya.

Kumagai, Gakuji (2016b). The logical problem of loanword adaptation and hidden phonology. Doctoral dissertation, Tokyo Metropolitan University.

Kumagai, Gakuji (2016c). The logical problem of loanword adaptation: A case study of English sC clusters. Ms. Tokyo Metropolitan University.

Martínez-Paricio, Violeta (2012). Superfeet as recursion. Proceedings of the West Coast Conference on Formal Linguistics 30, ed. by Nathan Arnett and Ryan Bennett, 259-269. Somerville, MA: Cascadilla Proceedings Project.

Martínez-Paricio, Violeta (2013). An exploration of minimal and maximal metrical feet. Doctoral dissertation, University of Tromsø.

Neeleman, Ad \& J. van de Koot (2006). On syntactic and phonological representations. Lingua 116: 1524-1552.

Nespor, Marina \& Irene Vogel (1983). Prosodic structure above the word. Prosody: Models and measurements 14, ed. by Anne Cutler and D. Robert Ladd, 123-140.

Nespor, Marina \& Irene Vogel (1986/2007). Prosodic phonology. Dordrecht: Foris. (Prosodic phonology: With a new forword. Berlin, Mouton de Gruyter.)

Pinker, Steven \& Ray Jackendoff (2005). The faculty of language: What's special about it? Cognition 95, $201-236$.

Prince, Alan \& Paul Smolensky (1993/2004). Optimality Theory: Constraint interaction in generative grammar. Malden, MA \& Oxford, UK: Blackwell. 
Revithiadou, Anthi (2011). The phonological word. Companion to phonology, ed. by Marc van Oostendorp, Colin J. Ewen, Elizabeth V. Hume, and Keren Rice, 1204-1227. Oxford: Wiley-Blackwell.

Schütz, Albert (1978). English loanwords in Fijian. Fijian language studies: Borrowing and pidginization. Bulletin of Fiji museum 4, ed. by Albert Schütz, 1-50.

Schütz, Albert (1983). The accenting of English loanwords in Fijian. Essays in honor of Charles F. Hockett, ed. by Frederick B. Agard, Gerald Kelley, Adam Makkai, and Valerie Becker Makkai, 565-572. Leiden: E. J. Brill.

Schütz, Albert (1985). The Fijian language. Honolulu: University of Hawaii Press.

Schütz, Albert (2004). English loan words in Fijian. Borrowing: A Pacific perspective, ed. by Jan Tent and Paul Geraghty, 253-294. Canberra: Pacific Linguistics, Research School of Pacific and Asian Studies, Australian National University. (A revised version of Schütz 1978).

Selkirk, Elizabeth (1980). The role of prosodic categories in English word stress. Linguistic Inquiry 11, 563-605.

Selkirk, Elizabeth (1984). Phonology and syntax: The relation between sound and structure. Cambridge, MA: The MIT Press.

Selkirk, Elizabeth (1996). Prosodic structure of function words. Signal to syntax: Prosodic bootstrapping from speech to grammar in early acquisition, ed. by James L. Morgan and Katherine Demuth, 187-214. Mahwah, NJ: Lawrence Erlbaum.

Selkirk, Elizabeth (2009). On clause and intonational phrase in Japanese. Gengo Kenkyu (Journal of the Linguistic Society of Japan) 136, 35-73.

Shinohara, Shigeko (2006). Perceptual effects in final cluster reduction patterns. Lingua 116, 1046-1078.

Smolensky, Paul (1993). Harmony, markedness, and phonological activity. [Rutgers Optimality Archive no.87].

Smolensky, Paul (1995). On the internal structure of the constraint component CON and UG. [Rutgers Optimality Archive no.86].

Tsujimura, Natsuko (2006). An introduction to Japanese linguistics. Oxford: Blackwell.

Uffmann, Christian (2007). Vowel epenthesis in loanword adaptation. Tübingen: Max Niemeyer Verlag. 